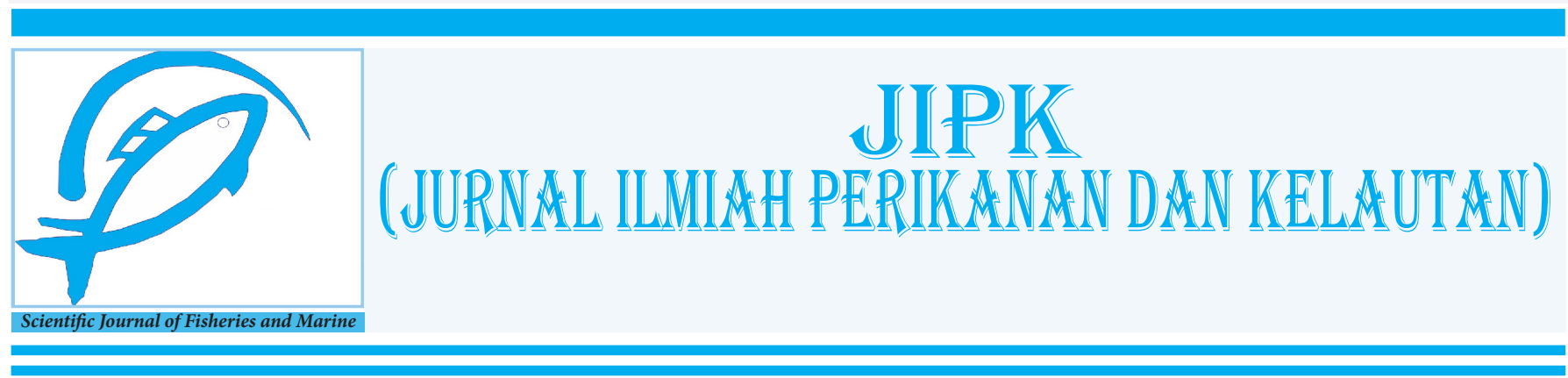

Research Article

\title{
Gene Transmission, Growth, and Exogeneous Growth Hormone Expression of G2 Transgenic Betta Fish (Betta imbellis)
}

\author{
Nadia Ayuningthias ${ }^{1}$, Hasan Nasrullah ${ }^{1}$, Dinar Tri Soelistyowati ${ }^{1}$, Eni Kusrini ${ }^{2}$, and Alimuddin Al- \\ imuddin $1 *$ (iD)
}

${ }^{1}$ Department of Aquaculture, Faculty of Fisheries and Marine Sciences, IPB University Bogor, West Java, 16680. Indonesia

${ }^{2}$ Research Institute for Ornamental Fish Culture, Ministry of Marine Affairs and Fisheries, Depok, West Java, 16436. Indonesia

\section{OPEN ACCESS}

\section{ARTICLE INFO}

Received: March 09, 2021

Accepted: May 31, 2021

Published: September 28, 2021

\section{*) Corresponding author: \\ E-mail: alimuddin@apps.ipb.ac.id}

Keywords:

Fish Growth

Giant Betta

GH Transgenic

Transgenesis

This is an open access article under the CC BY-NC-SA license (https://creativecommons.org/ licenses/by-nc-sa/4.0/)

\begin{abstract}
In our previous research, we had successfully produced $\mathrm{G}_{0}$ and $\mathrm{G}_{1}$ Pangasianodon hypophthalmus growth hormone $(P h \mathrm{GH})$ transgenic Betta imbellis, native ornamental betta from Indonesia, which it's giant- sized variant has valuable price for the breeders. The $\mathrm{G}_{0}$ and $\mathrm{G}_{1}$ transgenic (TG) fish showed higher growth rate and body size compared to the non-transgenic (NT) fish. The study was aimed to produce and evaluate the consistencies of transgene transmission and expression in $\mathrm{G}_{2}$ generation. The growth rate and body size between TG and NT fish was also compared. The $\mathrm{G}_{2}$ generation was produced using

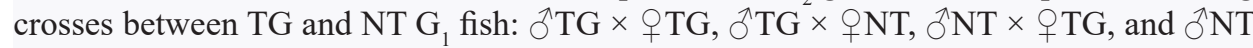
$\times \uparrow$ NT. Fish were reared for 12 weeks and transgene detection was performed using the polymerase chain reaction method from the caudal fin clips. The endogenous and exogenous GH expression analysis was conducted using the quantitative real-time PCR (qPCR) method. The results showed that the inheritance of the GH transgene by the $\mathrm{G}_{2}$ fish was more than $90 \%$ in all transgenic crosses. Endogenous GH was expressed at the same levels in the brain of TG and NT fish, but the exogenous GH expression was highly detected only in the TG fish. The $\mathrm{G}_{2}$ transgenic fish had a higher specific growth rate, up to $31 \%$, compared to the control. The body length of TG crosses were $23-35 \%$ higher and had $111-135 \%$ higher body weight compared to NT fish. These results showed a promising approached in mass-producing stable lines of giant-sized betta using the GH-transgenic technology.
\end{abstract}

Cite this as: Ayuningthias, N., Nasrullah, H., Soelistyowati, D. T., Kusrini, E., \& Alimuddin, A. (2021). Gene Transmission, Growth, and Exogeneous Growth Hormone Expression of G2 Transgenic Betta Fish (Betta imbellis). Jurnal Ilmiah Perikanan dan Kelautan, 13(2):181-189. http://doi.org/10.20473/jipk.v13i1.25870 


\section{Introduction}

Transgenesis is an important genetic experimental tool used to change or adjust animal traits to be useful in scientific research, biomedical study, and aquaculture by inserting a gene into an organism's genome (Dunham and Winn, 2014). For aquaculture purposes, this gene manipulation has primarily concentrated on elevating the fish growth rates to enhance production efficiency by shortening production times in many species (Devlin, 2011). This technique has shown promising results for increasing fish growth and body size in some fish species, including some with high commercial demand for human consumption, such as carp (Fu et al., 2007; Kurdianto et al., 2016), salmonid (Devlin et al., 2004), loach (Nam et al., 2001), and tilapia (Kobayashi et al., 2007). Beside the consumable fish, the transgenesis method is also potentially applied in the ornamental fish culture, mostly to enhance its color appearance (Gong et al., 2003; Rezaei et al., 2019). The application of the GH- transgenesis method in ornamental fish is still scarce.

Betta fish (Betta spp.) is an elegant tropical freshwater fish that is popular as a pet and mostly kept in home aquariums. In the wild, this genus is native from Thailand, Cambodia, Indonesia, and also present in other Southeast Asian countries (Kusrini, et al., 2016; Panijpan et al., 2014). They are domesticated from the wild and desired mostly for their appealing body-color, fin shape, and color pattern (Panijpan et al., 2020). Nowadays, giant-sized betta becomes one of the favorable variants, sought by the breeders due to its high price. In Indonesia, the breeders are trying to produce giant-sized betta variants, 1-3 times larger than normal size, through selective breeding. However, there are still some inconsistencies in the fish size and the number of the progenies that reach the giant-size is less than $10 \%$ per-spawning cycle (unpublished data). One of the alternative methods to consistently produce giant betta is through the transgenic method and then breeds the germ-line transmitted fish to mass produce the transgenic giant betta progenies. Previous studies have shown that the genetic transformation of fish with the growth hormone transgenic method resulted in significant improvements in weight gain and growth rate of fish. Second-generation of GH-transgenic mud loach Misgurnus mizolepis growth was accelerated up to 35 times higher than no-transgenic fish (Nam et al., 2001), and about 30 times in Coho salmon Oncorhynchus kisutch (Devlin et al., 2004). In 16-month-old $\mathrm{G}_{2}$ transgenic Nile tilapia Oreochromis niloticus, the average growth of the fish weight was $300-500 \%$ higher than control with the same rearing time (Kobayashi et al., 2007). Growth-hormone transgenic technology also potentially used to increase the growth.

In our recent study, we have successfully produced $\mathrm{G}_{0}$ and $\mathrm{G}_{1} \mathrm{GH}$-transgenic fish of the $B$. imbellis, native ornamental betta from Indonesia (Kusrini et al., 2018; Kusrini et al., 2016a). The gene introduction was conducted using the $\mathrm{p} C c \mathrm{BA}-P h \mathrm{GH}$ vector that consisted of the P. hypophthalmus GH cDNA and regulated by C. carpio $\beta$-actin promoter (Dewi et al., 2012). The fish were maintained in the controlled indoor rearing facility in the Research Institute for Ornamental Fish Aquaculture, Depok, West Java, Indonesia. Previously, The $\mathrm{G}_{0}$ transgenic fish showed $37.8 \%$ higher body weight than non-transgenic control after 7 months of rearing, and the $P h \mathrm{GH}$ cDNA was detected in the various tissues after PCR amplification (Kusrini et al., 2016a; Kusrini et al., 2016b). Furthermore, the $\mathrm{G}_{1}$ transgenic was produced from three different crosses of $\mathrm{G}_{0}$ : transgenic (TG) male and non-transgenic (NT) female, NT male paired with TG female, and NT transgenic fish pair as a control. Transgene transmission in $\mathrm{G}_{1}$ was about $62.5 \%$. Comparing to the non-transgenic fish, the $\mathrm{G}_{1}$ transgenic had $47 \%$ and $76 \%$ higher growth rate, and $32 \%$ and $25 \%$

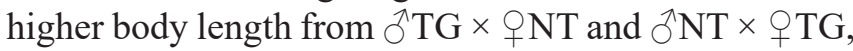
respectively, at five months old (Kusrini et al., 2018).

These previous studies showed promising results regarding the production of the giant variation of betta fish. However, the $G_{0}$ fish are mosaics with varying $\mathrm{GH}$ expression levels between individuals. $\mathrm{G}_{1}$ fish also possessed very large variation in expression between individuals even from the same $\mathrm{G}_{0}$ fish, and relatively low transmission (Kusrini et al., 2018). The $\mathrm{G}_{2}$ fish will probably possessed higher transmission with phenotypes that match the target and had high exogenous $\mathrm{GH}$ expression. This $\mathrm{G}_{2}$ fish are very important to make transgenic homozygote, where these homozygous transgenic fish will be used for mass transgenic fish production (Kurdianto et al., 2016). However, the $\mathrm{G}_{2}$ generation of $\mathrm{GH}$ transgenic betta was not produced yet. This study was aimed to produce and evaluate the consistencies of transgene transmission and $P h \mathrm{GH}$ expression in $\mathrm{G}_{2}$ transgenic $B$. imbellis and also compared the growth rate and body length between transgenic and non-transgenic progenies.

\section{Materials and Methods}

The care and use of experimental animals complied with IPB University and Research Institute for Ornamental Fish Culture animal welfare and experimentation guidelines.

\subsection{Material}

The $\mathrm{G}_{0}$ growth hormone transgenic $B$. imbellis 
were produced previously by transfection method of $\mathrm{p} C c \mathrm{Ba}-P h \mathrm{GH}$ expression vector (Dewi et al., 2012) into the fertilized eggs of $B$. imbellis (Kusrini et al., 2016). The $G_{1}$ progenies were obtained through reciprocal crosses of male/female transgenic $G_{0}$ with non-transgenic fish. The $G_{2}$ transgenic was produced from reciprocal crosses of $G_{1}$ transgenic fish. The fish were obtained from the Research Institute for Ornamental Fish Culture, Depok, West Java, Indonesia, and then reared in the same facility. Other materials were Artemia for feeding (Supreme Plus ${ }^{\mathrm{TM}}$, Golden West, USA), GeneJET Genomic DNA Purification Kit (Thermo Scientific, USA), oligonucleotide primers (IDT, Singapore), cDNA synthesis kit Revertra ${ }^{\circledR}$ Ace
qPCR RT Mastermix with gDNA removal (Toyobo, Japan), DNA ladders and loading dye(Invitrogen, USA), Go-Taq ${ }^{\circledR}$ Green Mastermix (Promega, USA), TRI Reagent ${ }^{\circledR}$ (Sigma-Aldrich, USA), nucleases-free water ( $1^{\text {st }}$ base, Malaysia), alcohol (chloroform, isopropanol, ethano196\% pro-analyst; Merck, USA), filtered microtips and sterile microtubes (ExtraGene, Taiwan). Equipment used for this study were peqSTAR Thermocycler (VWR, Austria), electrophoresis chamber and UV-illuminator (Bio- Rad's Sub-Cell@ System and Power Pac ${ }^{\mathrm{TM}}$, Bio-Rad, USA), Rotor-Gene 6000 qPCR machine (Qiagen, USA), refrigerated centrifuge (VWR, Austria), GeneQuant DNA Calculator (Pharmacia Biotech, USA), and various volumes of micropipettes (Axygen, USA).

Table 1. A reciprocal cross between transgenic and non-transgenic B. imbellis to produce $\mathrm{G}_{2}$ progenies

\begin{tabular}{|c|c|c|}
\hline \multirow[t]{2}{*}{ Male fish $(\circlearrowleft)$} & \multicolumn{2}{|c|}{ Female fish $(+)$} \\
\hline & TG & NT \\
\hline TG & $\S \mathrm{TG} \times \stackrel{\mathrm{T} G}{\mathrm{~T}}$ & $\delta \mathrm{TG} \times \stackrel{\circ \mathrm{NT}}{\mathrm{O}}$ \\
\hline NT & ${ }^{\top} \mathrm{NT} \times{ }_{+} \mathrm{TG}$ & $\hat{\mathrm{N} T} \times{ }_{+} \mathrm{NT}$ \\
\hline
\end{tabular}

Description: $\mathrm{TG}=$ transgenic, $\mathrm{NT}=$ non-transgenic. Each cross consists of three pairs of fish $(\mathrm{n}=3$ replication each cross).

Table 2. Primers sequence used in this study

\begin{tabular}{|c|c|c|c|}
\hline $\begin{array}{l}\text { Primer } \\
\text { Name }\end{array}$ & Sequence $\left(5^{\prime}-3^{\prime}\right)$ & $\begin{array}{l}\text { Annealing } \\
\text { Temperature }\left({ }^{\circ} \mathrm{C}\right)\end{array}$ & Application \\
\hline $\begin{array}{l}\text { PhGH-Fw } \\
\text { PhGH-Rv }\end{array}$ & $\begin{array}{l}\text { TCTTTAGTCAAGGCGCGACATTCGAGA } \\
\text { CGATAAGCACGCCGATGCCCATTTTCA }\end{array}$ & 65 & $\begin{array}{l}\text { PhGH transgene } \\
\text { screening }\end{array}$ \\
\hline $\begin{array}{l}\beta \text {-actin-Fw } \\
\beta \text {-actin-Rv }\end{array}$ & $\begin{array}{l}\text { TATGAAGGTTATGCTCTGCCC } \\
\text { CATACCCAGGAAAGATGGCTG }\end{array}$ & 60 & $\begin{array}{l}\text { PCR internal } \\
\text { control }\end{array}$ \\
\hline $\begin{array}{l}\mathrm{q} B e \mathrm{GH}-\mathrm{Fw} \\
\mathrm{q} B e \mathrm{GH}-\mathrm{Rv}\end{array}$ & $\begin{array}{l}\text { TGGAGGTTCTGCTCAAAGATAC } \\
\text { CATCTCTACACCATCCTCATTGG }\end{array}$ & 60 & qPCR of $B e G H$ \\
\hline $\begin{array}{l}\text { qIGF-1-Fw } \\
\text { qIGF-1-Rv }\end{array}$ & $\begin{array}{l}\text { TGTTTGTGTGCGGAG ATAGAG } \\
\text { CTCACAGCTCTGGAAGCAG }\end{array}$ & 60 & qPCR of IGF-1 \\
\hline $\begin{array}{l}\text { qPhGH1-Fv } \\
\text { qPhGH1-Rv }\end{array}$ & $\begin{array}{l}\text { CGAGGATTTCTACCAGACCTTG } \\
\text { GCTGAGATAGGTCTCCACTTTG }\end{array}$ & 60 & qPCR of $P h G H$ \\
\hline $\begin{array}{l}\text { EF-1 } 1 \alpha-F w \\
\text { EF-1 } 1 \alpha-R v\end{array}$ & $\begin{array}{l}\text { GGTGTGAAGCAGCTCATCGTTGGT } \\
\text { AGAGATGGGGACAAAGGCAACAG }\end{array}$ & 60 & $\begin{array}{l}\text { qPCR } \\
\text { normalizator, } \\
\text { internal control }\end{array}$ \\
\hline
\end{tabular}

Table 3. Transgene transmission in $\mathrm{G}_{1}$, and $\mathrm{G}_{2}$ Betta imbellis

\begin{tabular}{|c|c|c|}
\hline \multirow{2}{*}{ Crosses } & \multicolumn{2}{|c|}{ Transgene transmission } \\
\hline & $\mathbf{G}_{1 *}$ & $\mathbf{G}_{2}$ \\
\hline$\tilde{N} \mathrm{NT} \times q \mathrm{NT}$ & 0.00 & 0.00 \\
\hline$\delta \mathrm{NT} \times q \mathrm{TG}$ & 66.67 & 96.66 \\
\hline$\hat{\mathrm{TG}} \times q \mathrm{NT}$ & 58.93 & 90.00 \\
\hline$\delta \mathrm{TG} \times q \mathrm{TG}$ & n.d & 96.66 \\
\hline
\end{tabular}

* from previous study (Kusrini et al., 2018). Description: $\mathrm{n}=30$ for each cross. $\mathrm{NT}=\mathrm{G}_{1}$ non-transgenic, $\mathrm{TG}=\mathrm{G}_{1}$ transgenic. $\mathrm{N} . \mathrm{d}=$ not determined. 


\subsection{Method}

\subsubsection{Experimental design and fish rearing}

Mature $\mathrm{G}_{1}$ of transgenic (TG) male $(4.7 \pm 0.6 \mathrm{~cm}$; $1.2 \pm 0.5 \mathrm{~g})$, TG female $(4.4 \pm 0.3 \mathrm{~cm} ; 1.3 \pm 0.3 \mathrm{~g})$, nontransgenic (NT) male $(3.17 \pm 0.21 \mathrm{~cm} ; 0.79 \pm 0.24 \mathrm{~g})$, and NT female $(3.40 \pm 0.17 \mathrm{~cm} ; 1.04 \pm 0.19 \mathrm{~g})$ that were in the same age were used in the reciprocal crossing to produce $\mathrm{G}_{2}$ progenies. Transgenic crosses were ${ }^{\lambda} \mathrm{TG} \times$

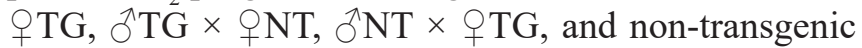
$\checkmark \mathrm{NT} \times q$ NT cross as control (Table 1). The spawning process was conducted in pair (1:1) inside the plastic buckets $(\mathrm{d}=40 \mathrm{~cm})$ with $7.5 \mathrm{~L}$ of water volume. Eggs were collected and placed in the $50 \times 60 \times 90 \mathrm{~cm}^{3}$ tanks. After hatching, $\mathrm{G}_{2}$ fish were reared for 5 months. The larva was fed with Artemia nauplius starting from day 2 until 14 days after hatching (DAH). Then, fish were fed with Moina sp. and chopped Tubifex sp. until it reached 1 month DAH. Tubifex and bloodworm were given until fish reach 3 months DAH. All progenies from each cross were fed with the same amount of feed during the rearing period. Waste was removed daily and $50 \%$ water change was done every 3 days. At two months old, sex differentiation was conducted and male fish were reared separately. Male progenies were reared individually (1 fish per-tank), while female progenies were reared in the same rearing tank (10 fish $\left.\mathrm{L}^{-1}\right)$. Fish bodyweight and length were measured every week randomly within the population without prior DNA analysis $(\mathrm{n}=40$ fish each cross).

\subsubsection{Transgene transmission}

Fin clips were taken from six weeks old $\mathrm{G}_{2}$ progenies $(\mathrm{n}=30$ from each cross) to screen the $P h \mathrm{GH}$ transgene within the genome. The screening was done using the polymerase chain reaction (PCR) method. Genomic DNA from the fins was isolated and amplified using the specific $P h \mathrm{GH}$ primer that amplifies the exogenous GH cDNA sequence. The primer was consisted of $P h \mathrm{GH}$ forward: 5'-TCTTTAGTCAAGGCGCGACATTCGAGA-3' and the reverse sequence was: 5'CGATA A GCACGCCGATGCCCATTTTCA-3'. The $\beta$-actin gene was used for the PCR internal control with forward sequence: 5'-TATGAAGGTTATGCTCTGCCC-3' and reverse sequence: 5'- CATACCCAGGAAAGATGGCTG-3' (Table 2). The PCR program and reaction were based on our previous result (Dewi et al., 2012). The amplification result was visualized under the UV-light after the gel electrophoresis separation. Positive $P h \mathrm{GH}$ transgene fish will produce a single band at $334 \mathrm{bp}$ while no-transgene fish will have no observed DNA band after gel electrophoresis

\subsubsection{Total RNA extraction and $m R N A$ expression}

Total RNA was extracted from the brain of the transgenic progenies from the $\mathrm{TG} \times \mathrm{TG}$ cross and nontransgenic control from NT $\times$ NT cross $(n=3$ from each cross). The total RNA was extracted and its concentration was measured using a spectrophotometer at 260 and 280 $\mathrm{nm}$. The cDNA synthesis was conducted from $100 \mathrm{ng}$ $\mu \mathrm{L}^{-1}$ of total RNA. The qPCR reaction was performed to determine the mRNA expression levels of the growthrelated gene. The endogenous $B$. imbellis growth hormone $(\mathrm{Be} \mathrm{GH})$, and exogenous $\mathrm{PhGH}$ expression in transgenic and non-transgenic $\mathrm{G}_{2}$ progenies were evaluated using the specific primers (Table 2). The qPCR reaction was performed with the total reaction volume was $20 \mu \mathrm{L}$, consisted of $10 \mu \mathrm{L} 2 \times$ sensiFAST SYBR NO-ROX mix (Bioline, UK), $0.8 \mu \mathrm{L}$ of each specific primer, $4 \mu \mathrm{L}$ cDNA, and $4.4 \mu \mathrm{L} \mathrm{NFW} \mathrm{(nucleases-free}$ water). The amplification program was conducted in the Rotor-Gene 6000 (Corrbet, USA) with Green channel to detect the florescence dye $(470 \mathrm{~nm}$ for source, and $530 \mathrm{~nm}$ for the detector). The qPCR program was set at $95^{\circ} \mathrm{C}$ for $3 \mathrm{~min}$, continued with 40 cycles of $95^{\circ} \mathrm{C}$ for $10 \mathrm{~s}, 60^{\circ} \mathrm{C}$ for $15 \mathrm{~s}$, and $72^{\circ} \mathrm{C}$ for $15 \mathrm{~s}$. Melting-curve analysis was performed at the end of the amplification reaction to evaluate the specificity of the amplification. The melting curve analysis was performed at $72-95^{\circ} \mathrm{C}$ with $1{ }^{\circ} \mathrm{C}$ resolution per-second at Rotor-Gene 6000 machine. All molecular works were performed using the sterile-filtered microtips and tubes (Extra Gene, Taiwan).

\subsection{Analysis Data}

The transgene transmission data were compared descriptively while the growth performance, growth pattern, and mRNA expression data were compared statistically using the one-way ANOVA analysis followed by Duncan's test at $\alpha=0.05$. The expression levels after qPCR analysis were normalized to the elongation factor- $1 \alpha(\mathrm{EF} 1 \alpha)$ gene and analyzed using the $2^{-\Delta \Delta \mathrm{Ct}}$ method (Livak and Schmittgen, 2001).

\section{Results and Discussion}

The growth process in fish is regulated through the growth hormone synthesized in hypophysis and then it is released into the bloodstream. The GH protein will interact with its specific receptors on the cells and altered the intracellular-somatotrophic signaling pathways, with insulin-like growth factor 1 (IGF-1) as the main mediator for cell proliferation and growth (Fuentes et al., 2013; Nipkow et al., 2018). Although not common, 
the application of GH transgenesis in ornamental fish is also potential to increase fish growth rate and reduce its production period. In this study, the $\mathrm{G}_{2}$ generation of GH-transgenic betta is successfully produced using various crosses of TG and NT fish to obtain giantsized betta fish. PCR analysis confirmed the presence of the transgene in the purified genomic DNA from the $\mathrm{G}_{2}$ progenies from different crosses groups, except the control (Figure 2). The $\beta$-actin as an internal control was amplified in all fish and the non-template control was not contaminated. The amplicon size of the $P h \mathrm{GH}$ DNA was similar between the plasmid control and sample DNA. The PCR product, corresponding to 334 bp of the specific $P h \mathrm{GH}$ cDNA sequence, was detected in 29 of $30(96.67 \%)$ progenies of $\lesssim \mathrm{NT} \times q \mathrm{TG}, 27$ of $30(90 \%)$ from ${ }^{\wedge} \mathrm{TG} \times$ ONT, 29 of 30 (96.67\%) from $\lesssim \mathrm{TG} \times q \mathrm{TG}$, and was not detected in any of the control fish from ${ }^{\lambda} \mathrm{NT} \times q \mathrm{NT}$ (Table 3 ). The inheritance was significantly increased from its $\mathrm{G}_{1}$ generation. Previously, the gene transmission from the $\mathrm{G}_{0}$ to the $\mathrm{G}_{1}$ progenies was 58.89-66.67\% (Kusrini et al., 2018). The transgene transmission was more than expected for Mendelian segregation of single locus. This pattern suggested that the transgene DNA might be integrated at multipleloci in founder fish, and thus inherited stably (Chen et al., 2015; Devlin et al., 2004).

\section{Transgenic}

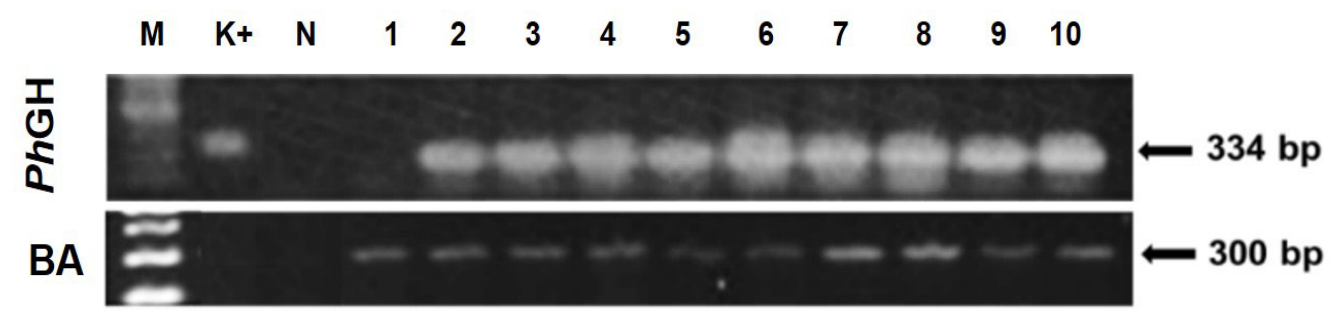

\section{Non-Transgenic}

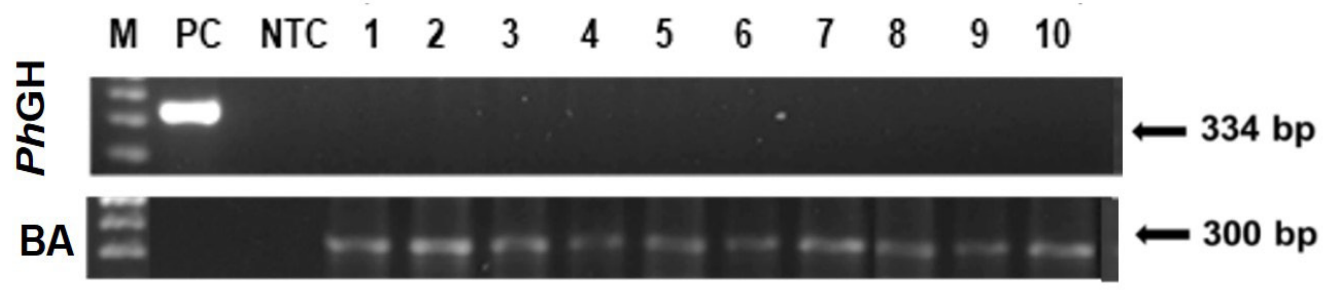

Figure 1. PCR detection of the $P h \mathrm{GH}$ gene in the purified genomic DNA from $\mathrm{G}_{2}$ transgenic and nontransgenic $B$. imbellis. $\mathrm{M}=100$ bp DNA ladder, $\mathrm{K}+=C c \mathrm{BA}-P h \mathrm{GH}$ vector, $\mathrm{N}=$ no-template control, $1-10=$ sample number.

Table 4. Growth performance and survival of transgenic $\mathrm{G}_{2}$ Betta imbelis from different crosses

\begin{tabular}{|c|c|c|c|c|}
\hline \multirow{2}{*}{ Parameter } & \multicolumn{4}{|l|}{ Crosses } \\
\hline & $3 \mathbf{N T} \times q \mathbf{N T}$ & 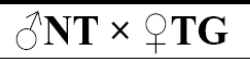 & $\jmath^{1} \mathbf{T G} \times q \mathbf{N T}$ & $\precsim \mathbf{T G} \times{ }_{+} \mathbf{T G}$ \\
\hline $\begin{array}{l}\text { Body length growth (cm } \\
\text { day }^{-1} \text { ) }\end{array}$ & $0.374 \pm 0.02 b$ & $0.442 \pm 0.03 \mathrm{a}$ & $0.444 \pm 0.278 \mathrm{a}$ & $0.415 \pm 0.032 \mathrm{a}$ \\
\hline $\begin{array}{l}\text { Body weight growth } \\
\left(\text { gram day }^{-1}\right)\end{array}$ & $0.031 \pm 0.001 \mathrm{~b}$ & $0.039 \pm 0.002 \mathrm{a}$ & $0.04 \pm 0.002 \mathrm{a}$ & $0.04 \pm 0.002 \mathrm{a}$ \\
\hline $\begin{array}{l}\text { Specific growth rate }(\% \\
\left.\text { day }^{-1}\right)\end{array}$ & $2.689 \pm 0.078 b$ & $3.5340 .169 \mathrm{a}$ & $3.474 \pm 0.142 \mathrm{a}$ & $3.511 \pm 0.101 \mathrm{a}$ \\
\hline Survival $(\%)$ & $81 \pm 2.29 a$ & $81 \pm 3.46 \mathrm{a}$ & $79 \pm 2.96 \mathrm{a}$ & $80 \pm 2.22 \mathrm{a}$ \\
\hline
\end{tabular}

Description: $\mathrm{TG}=$ transgenic $\mathrm{G}_{1} ; \mathrm{NT}=$ Non-transgenic $\mathrm{G}_{1}$. Different letters indicate a significant difference between crosses. 

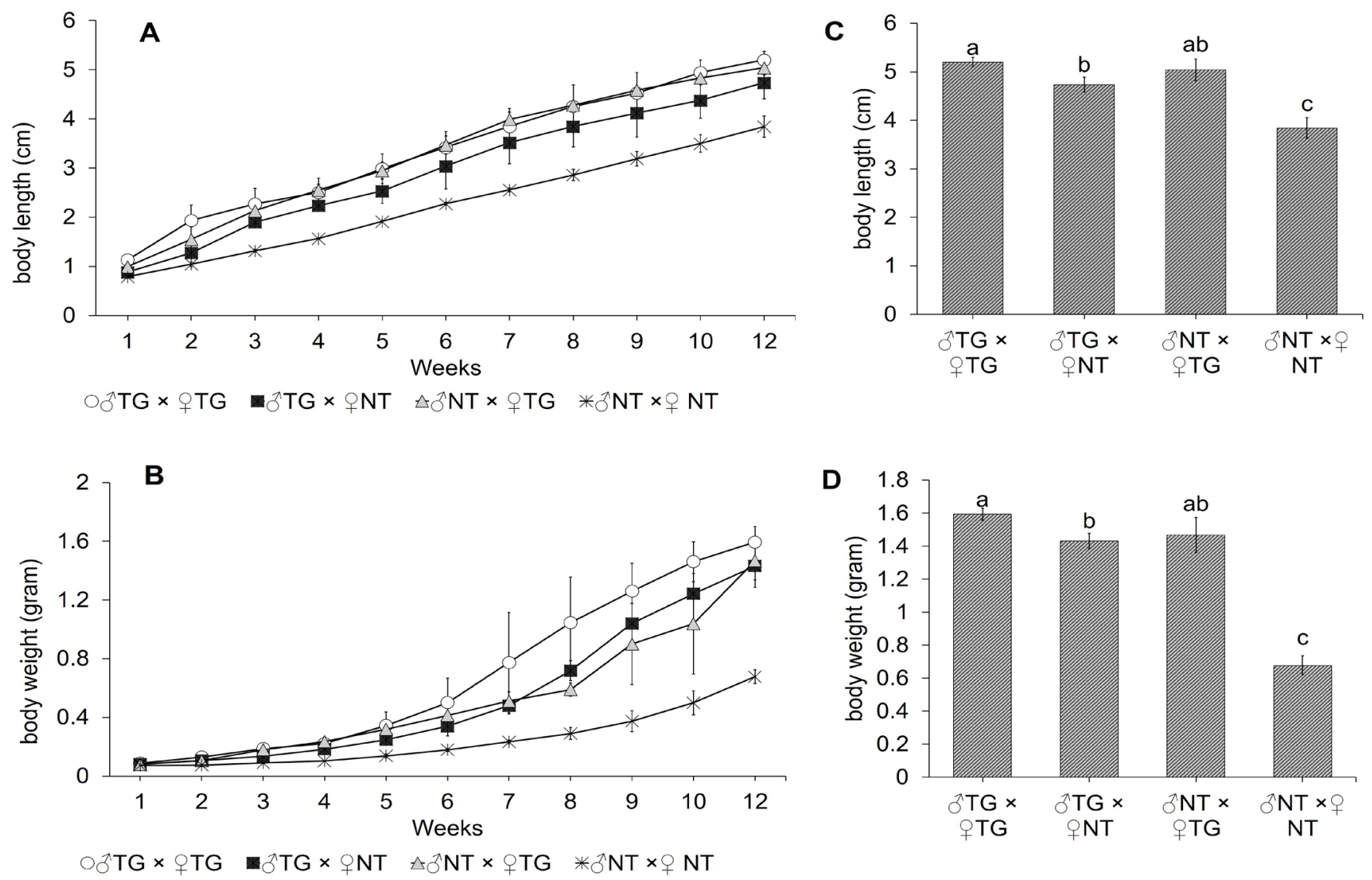

Figure 2. Body length and body weight of $\mathrm{G}_{2}$ transgenic and non-transgenic $B$. imbellis. Bodyweight (A) and body length (B) pattern during 12 weeks of rearing and size comparison of all crosses at the end of the experiment (C and D) are shown. Data were presented as mean \pm S.D with the error bar. However, in several points, the error bar was smaller than the marker, thus not shown in the figure. Different letters in the bar graph indicate a significant difference between progenies from different crosses $(\mathrm{p}<0.05)$.

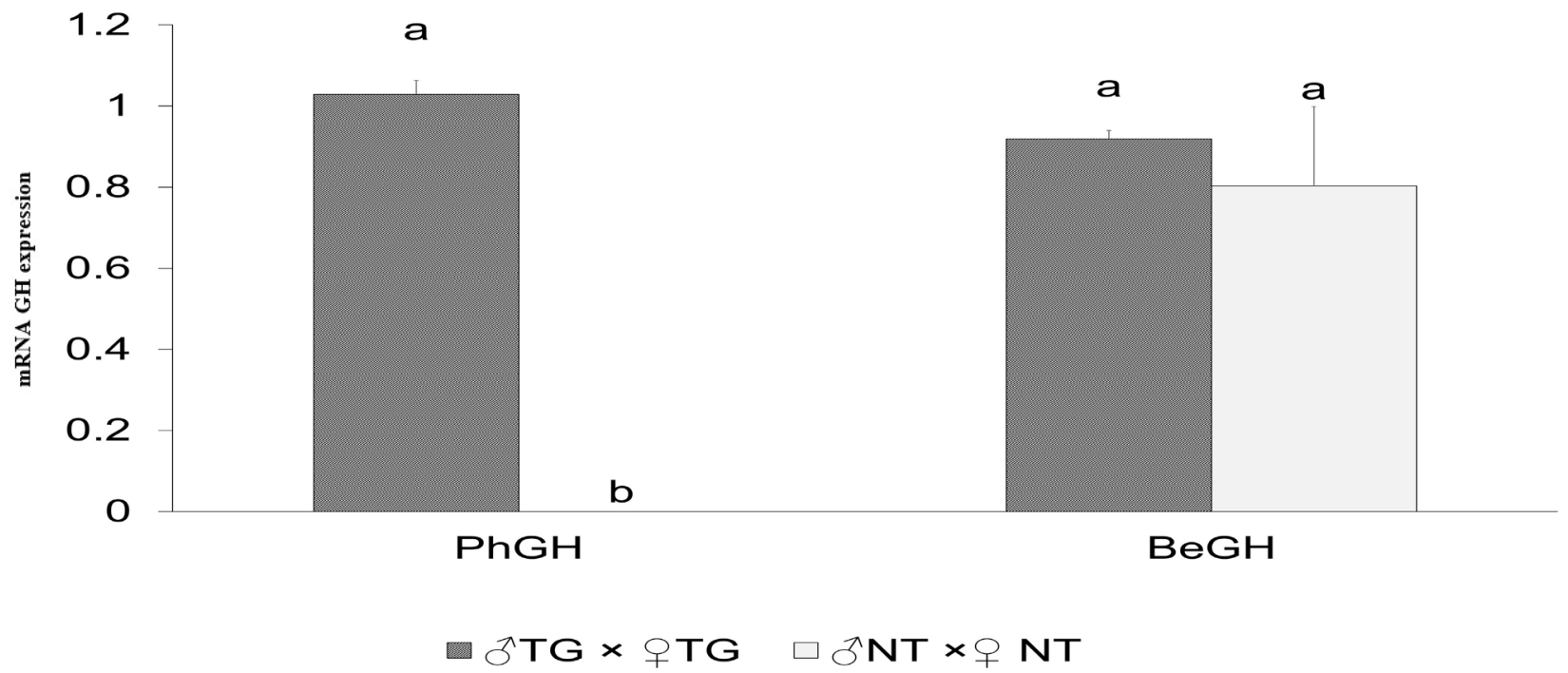

Figure 3. The relative mRNA expression of transgene $P h \mathrm{GH}$ and endogeneous $B e \mathrm{GH}$ of $\mathrm{G}_{2}$ transgenic and non-transgenic $B$. imbellis. No PhGH mRNA transcript was detected in male $\mathrm{NT} \times$ female NT non-transgenic control. Data were presented as mean $\pm \mathrm{SD}$. Different letters indicate a significant difference in the mRNA expression of the same gene among crosses $(p<0.05)$. 
The results showed that the body length and

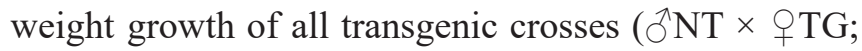

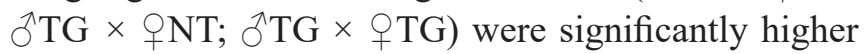

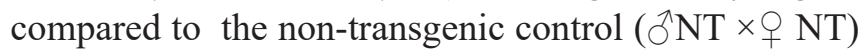
(Table 4). The progenies from the transgenic crosses also had a higher specific growth rate, up to $31.2 \%$, compared to the control group with no significant difference in the fish survival. The results showed that the progenies from transgenic crosses had a higher average body length and weight during the 12-weeks of rearing compared to the non-transgenic control (Figure $2 \mathrm{~A}$ and $2 \mathrm{~B}$ ). The body length of fish from transgenic crosses was $23-35 \%$ higher than control. The ${ }^{2} \mathrm{TG} \times$ o TG progenies had higher body length compared to the

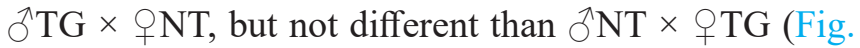
2C). Fish body weight showed the same results (Figure 2B). At the end of rearing, the $\mathrm{G}_{2}$ fish that came from transgenic crosses had a higher average body weight, $111-135 \%$ fold compared to NT control. The $3 \mathrm{TG} \times$ OTG progenies had higher body weight compared to the ${ }^{\top} \mathrm{TG} \times$ $\times \mathrm{NT}$, but not different than ${ }^{\top} \mathrm{NT} \times{ }_{+} \mathrm{TG}$ (Figure 2D). This result was not surprising since it was widely reported in other transgenic fish species that bearing the exogenous GH. In six months old zebrafish Danio rerio, GH transgenic fish reached about 155\% higher final average mass compared to its non-transgenic siblings (Figueiredo et al., 2007). In the tilapia GH-transgenic Nile tilapia, the body weight of $\mathrm{G}_{2}$-transgenic fish was 7 times larger compared to the non-transgenic control (Kobayashi et al., 2007). In the $\mathrm{G}_{2}$ generation of GHtransgenic common carp, specific growth was reported to be $77.4 \%$ higher than non-transgenic fish and had $69.2 \%$ times higher body weight (Fu et al., 2007).

This significant body weight and length alteration in TG fish might due to the overexpression of exogenous GH-transgene thus affect other growth factors (Triantaphyllopoulos et al., 2020). The PhGH mRNA transcripts were observed in the fish brain and only detected in TG fish (Figure 3). These results indicated that the $P h \mathrm{GH}$ DNA was successfully incorporated into the fish genome and undergone the transcription process. The expression of $\mathrm{PhGH}$ in the fish brain might have a not significant effect on the transcription of the endogenous $B e \mathrm{GH}$ since $B e \mathrm{GH}$ was expressed at the same levels in the brain of transgenic fish and nontransgenic control (Figure 3). However, in vivo protein translation of $P h \mathrm{GH}$ and $B e \mathrm{GH}$ was not analyzed in this study and needs to be evaluated in the future. This transcription of $P h \mathrm{GH}$ mRNA potentially leads to a significant increase in the GH synthesis, thus resulting in a significant growth rate of TG fish compared to the NT fish (Table 4 and Figure 2). Moreover, compared to the $G_{1}$ fish, $G_{2}$ betta had a faster growth rate and larger body weight at the same rearing points. The $\mathrm{G}_{1}$ TG progenies reached $0.4-0.8 \mathrm{~g}$ of body weight, $2.7-3.5$ $\mathrm{cm}$ of body length after 12 weeks (Kusrini et al., 2018), while in $\mathrm{G}_{2}$ fish it was already reached $0.67-1.59 \mathrm{~g}$ for bodyweight and $3.8-5 \mathrm{~cm}$ for body length within the same rearing period (Figure 2). Taking together, the $\mathrm{G}_{2}$ progenies inherited a higher percentage of $\mathrm{GH}$ transgene and possessed a higher growth rate compared to its $G_{1}$ generation. This might be beneficial for the large and stable production of giant-sized ornamental betta fish. However the commercial use of genetically modified fish in aquaculture is still up for discussion, since the first commercialization of genetically modified fish, GloFish, was in 2003 (Gong et al., 2003), and further, the United States and Canada allowed the commercial processing and selling of the AquAdvantage ${ }^{\circledR}$ Salmon (Ledford, 2015). To prevent potential adverse impact on the environment, biological and environmental containments should be applied in the production of TG betta, for example using the closed containment aquaculture system (Crouse et al., 2021). Furthermore, the transgenic betta should be bred as sterile-triploid fish to avoid reproduction. As example, the transgeniccommercial AquAdvantage ${ }^{\circledR}$ salmon are produced as triploid females, which do not contain fertile gametes and thus have little reproductive potential. They are therefore incompatible with wild diploid fish (Ignatz et al., 2020).

\section{Conclusion}

The $G_{2}$ generation of $\mathrm{GH}$ TG betta had been successfully produced, with more than $90 \%$ of the inherited transgene. Endogenous GH was expressed at the same levels in the TG and NT, but the exogenous $\mathrm{GH}$ was only detected in the TG fish. The growth of $\mathrm{G}_{2}$ TG fish was up to $31.2 \%$ higher than control and $\mathrm{TG}$ crosses had significantly higher body weight and length compared to NT. Moreover, $\mathrm{G}_{2}$ TG fish reached a larger body length and weight in a shorter period compared to $G_{1}$. These results showed a promising approached in mass-producing giant-sized betta using the GHtransgenic technology.

\section{Acknowledgment}

The authors thank Ms. Dian Novita Sari, Ms. Anzila R.W. Muharrama, and all laboratory staff of Research Institute for Ornamental Fish Culture, Depok, 
Indonesia for their excellent help with this study.

\section{Authors' Contributions}

All authors have contributed to the final manuscript. The contribution of each author as follows, NA and EK; reared the fish, collected the data, performed PCR analysis, drafted the manuscript, AMD and DTS; devised the main conceptual ideas, analyzed and evaluated the final data, and done critical revisions of the manuscript, HN; performed qPCR experiment and analysis, designed the figures and tables, finalized the manuscript. All authors discussed the results and contributed to the final manuscript equally.

\section{Conflict of Interest} interests.

The authors declare that they have no competing

\section{Funding Information}

This research was partially supported by the Ministry of Research and Higher Education of the Republic of Indonesia with grant number: 1629/IT3.11/ $\mathrm{PN} / 2018$ in 2018.

\section{References}

Chen, J., Luo, Q., Bao, H., Liao, L., Li, Y., Zhu, Z., Wang, Y., \& Hu, W. (2015). The integration characteristics of the exogenous growth hormone gene in a transgenic common carp (Cyprinus carpio L.) with fast-growth performance. Science Bulletin, 60(19):1654-1660.

Crouse, C., Davidson, J., May, T., Summerfelt, S., \& Good, C. (2021). Production of market-size European strain Atlantic salmon (Salmo salar) in land-based freshwater closed containment aquaculture systems. Aquacultural Engineering, 92:102-138.

Devlin, R. H. (2011). Cellular, molecular, genomics, and biomedical approaches | Growth hormone overexpression in transgenic fish. In Encyclopedia of Fish Physiology (Vol. 3, pp. 2016-2024). Elsevier Inc.

Devlin, R. H., Biagi, C. A., \& Yesaki, T. Y. (2004). Growth, viability and genetic characteristics of $\mathrm{GH}$ transgenic coho salmon strains. Aquaculture, 236(1-4):607-632.
Dewi, R. R. S. P. S., Alimuddin, Sudrajat, A. O., \& Sumantadinata, K. (2012). The effectivity of gene transfer and expression of $P h \mathrm{GH}$ in stripped catfish (Pangasianodon hypophthalmus). Jurnal Riset Akuakultur, 7(2): 171-180.

Dunham, R. A., \& Winn, R. N. (2014). Production of Transgenic Fish. In Transgenic animal technology: A laboratory handbook: Third Edition (pp. 305334). Elsevier Inc.

Figueiredo, M. A., Lanes, C. F. C., Almeida, D. V., Proietti, M. C., \& Marins, L. F. (2007). The effect of GH overexpression on GHR and IGF-I gene regulation in different genotypes of $\mathrm{GH}$-transgenic zebrafish. Comparative Biochemistry and Physiology Part D: Genomics and Proteomics, 2(3):228233.

Fu, C., Li, D., Hu, W., Wang, Y., \& Zhu, Z. (2007). Growth and energy budget of F2 "all-fish" growth hormone gene transgenic common carp. Journal of Fish Biology, 70(2):347-361.

Fuentes, E. N., Valdés, J. A., Molina, A., \& Björnsson, B. T. (2013). Regulation of skeletal muscle growth in fish by the growth hormone - Insulin-like growth factor system. General and Comparative Endocrinology, 192:136-148.

Gong, Z., Wan, H., Tay, T. L., Wang, H., Chen, M., \& Yan, T. (2003). Development of transgenic fish for ornamental and bioreactor by strong expression of fluorescent proteins in the skeletal muscle. Biochemical and Biophysical Research Communications, 308(1):58-63.

Ignatz, E. H., Dumas, A., Benfey, T. J., Hori, T. S., Braden, L. M., Runighan, C. D., Rise, M. L., \& Westcott, J. D. (2020). Growth performance and nutrient utilization of growth hormone transgenic female triploid Atlantic salmon (Salmo salar) reared at three temperatures in a land-based freshwater recirculating aquaculture system (RAS). Aquaculture, 519:734896.

Kobayashi, S. , Alimuddin, Morita, T., Miwa, M., Lu, J., Endo, M., Takeuchi, T., \& Yoshizaki, G.(2007). Transgenic nile tilapia (Oreochromis niloticus) over-expressing growth hormone show reduced ammonia excretion. Aquaculture, 270(1):427-435.

Kurdianto, Alimuddin, Faridah, N., Yoshizaki, G., Nuryati, S., \& Setiawati, M. (2016). Growth, survival, and body composition of transgenic common carp Cyprinus carpio 3rd generation expressing tilapia growth hormone cDNA. HAYATI 
JIPK. Volume 13 No 2. November 2021 / Gene Transmission, Growth, and Exogeneous Growth Hormone Expression.....

Journal of Biosciences, 23(3):150-154.

Kusrini, E., Alimuddin, Zairin, M. Jr., \& Sulistyowati, D. T. (2016a). Gene transfer on Betta imbellis through transfection method with different DNA concentration. Indonesian Aquaculture Journal, 11(1):1-7.

Kusrini, E., Zairin, M. Jr., \& Sulistyowati, D.T. (2016b). Identification of founder generation of betta fish (Bettaimbellis) growth hormone transgenic. Jurnal Riset Akuakultur, 11(3):197-205.

Kusrini, E., Alimuddin, Zairin Jr, M., \& Soelistyowati, D. T. (2018). Foreign growth hormone gene transmission and expression in F1 transgenic betta fish (Betta imbellis). Pakistan Journal of Biotechnology, 15(1):1-9.

Ledford, H. (2015). Transgenic salmon leaps the dinner table. Nature, 527:417-418.

Livak, K. J., \& Schmittgen, T. D. (2001). Analysis of relative gene expression data using real-time quantitative PCR and the 2- $\Delta \Delta \mathrm{CT}$ method. Methods, 25(4):402-408.

Nam, Y. K., Noh, J. J., Cho, Y. S., Cho, H. J., Cho, K. N., Kim, C. G., \& Kim, D. S. (2001). Dramatically accelerated growth and extraordinary gigantism of transgenic mud loach Misgurnus mizolepis. Transgenic Research, 10:353-362.

Nipkow, M., Wirthgen, E., Luft, P., Rebl, A., Hoeflich,
A., \& Goldammer, T. (2018). Characterization of IGF1 and IGF2 genes during maraena whitefish (Coregonus maraena) ontogeny and the effect of temperature on embryogenesis and IGF expression. Growth Hormone and IGF Research, 40:32-43.

Panijpan, B., Kowasupat, C., Laosinchai, P., Ruenwongsa, P., Phongdara, A., Senapin, S., Wanna, W., Phiwsaiya, K., Kühne, J., \& Fasquel, F. (2014). Southeast Asian mouth-brooding Betta fighting fish (Teleostei: Perciformes) species and their phylogenetic relationships based on mitochondrial COI and nuclear ITS1 DNA sequences and analyses. Meta Gene, 2:862-879.

Panijpan, B., Sriwattanarothai, N., \& Laosinchai, P. (2020). Wild betta fighting fish species in Thailand and other Southeast Asian countries. ScienceAsia, 46(4):382-391.

Rezaei, M., Basiri, M., Hasani, S. N., Asgari, B., Kashiri, H., Shabani, A., \& Baharvand, H. (2019). Establishment of a transgenic zebrafish expressing GFP in the skeletal muscle as an ornamentalfish. Galen Medical Journal, 8:1068.

Triantaphyllopoulos, K. A., Cartas, D., \& Miliou, H. (2020). Factors influencing GH and IGF-I gene expression on growth in teleost fish: how can aquaculture industry benefit? Reviews in Aquaculture, 12(3):1637-1662. 